\title{
Accelerated tests of coil coatings
}

\author{
B.M. Rosales*, J. Simancas** and S. Flores***
}

\begin{abstract}
Accelerated laboratory tests on 12 materials in study in the Subgroup 6 of the PATINA Network (CYTED), are discused for different exposition periods in salt spray, $\mathrm{SO}_{2}$ and Prohesion chambers. International standards used to evaluate failures caused by the different aggressive agents of these laboratory tests are the same as those applied for outdoor expositions. The results exposed contribute to a better understanding of the mechanisms occurred in the diverse natural environments, being mentioned the main analogies and differences respect to factors affecting natural tests. They also allowed to evidence the advantages and limitations in the application of these tests during several days, as compared to the years required to attain similar failure magnitudes through outdoor tests.
\end{abstract}

Keywords Accelerated test. Normalised test. Coil-coating.

\section{Ensayos acelerados de recubrimientos para banda continua}

Resumen En este trabajo se discuten los ensayos de laboratorio acelerados, realizados sobre 12 materiales de estudio en el Subgrupo 6 de la Red PATINA (CYTED), a diferentes periodos de exposición en cámaras de niebla salina, $\mathrm{SO}_{2}$ y Prohesion. Se utilizaron las normas internacionales para evaluar los fallos causados por los diferentes agentes agresivos de estos ensayos de laboratorio, las cuales se aplican también para los ensayos de exposición a la intemperie. Los resultados expuestos contribuyen a una mejor comprensión de los mecanismos ocurridos en los diversos ambientes naturales, mencionándose las principales analogías y diferencias respecto de los factores que afectan los ensayos naturales. También permitieron evidenciar las ventajas y limitaciones en la aplicación de estos ensayos durante varios días, en comparación con los años requeridos para alcanzar magnitudes de fallos similares por medio de ensayos a intemperie.

Palabras clave Ensayos acelerados. Ensayos normalizados. Recubrimiento para banda continua.

\section{INTRODUCTION}

The long duration of the outdoor tests, necessary to select on a performance basis among different corrosion protection schemas (paints, primers, oils, etc.) was the origin of the accelerated laboratory test.

The need to reproduce the effect of natural environments was a consequence of the distinct behaviour observed for a given system, according to the site where the material has been tested or has to spent its service life. However, the acceleration in the failure nucleation and propagation, with respect to that occurred in highly aggressive natural atmospheres, must consider the need to maintain the same degradation mechanism as in the natural environment. Thus, salt spray ${ }^{[1 \text { and } 2]}$ and $\mathrm{SO}_{2}{ }^{[3 \text { and } 4]}$ chambers, were developed and normalised to test protective systems in marine and industrial environments respectively. Prohesion ${ }^{[5]}$ is another test during which samples are submitted to alternate salt fog and drying periods in a laboratory chamber.

Each of these test provides the possibility of analising the separate effect of variables simultaneously acting on materials during natural exposures. They are usefull tools contributing to understand the mechanism of materials degradation in the atmosphere. However, there is not a single laboratory test able to cause the same

(*) CITEFA-DEICOR. Zufriategui 4380, (1603) Villa Martelli, Argentina.

(**) CENIM. Avda. Gregorio del Amo, 8, 28040, Madrid, España.

(***) ICP-PUCP. Avda. Universitaria cuadra $18 \mathrm{~s} / \mathrm{n}$ Lima 32, Perú. 
type and relative magnitude of damage, on determined set of protection schemas, as that produced by an aggressive natural atmosphere. On the contrary, this normalized set of test allows to reproduce them when desired, in well defined conditions. Different researchers from various laboratories can get results with such a low scatering, as cannot be done at any given time in natural atmospheres.

The experience developed in order to obtain more relyable resuts led to a series of normalissed equipment to simulate different atmospheric conditions, which cannot be extrapolated to the real situation it tries to simulate and accelerate, nor to give a time correlation, unless the performance comparison concerned a single type of materials.

Evaluation of the failures caused by the mentioned different simulated atmospheres was done by application of ISO 4628/82, 1 to $6^{[6-11]}$ standards, also followed to quantify type and magnitude of failures after outdoor tests.

\section{EXPERIMENTAL}

Coil-coatings of 12 different formulations, shown in table I, have been tested in 3 accelerated test chambers to determine the type and magnitude of failures observed for different exposure times, as compared to those found in 9 MICAT Test Stations of distinct natural atmospheric conditons, up to 42 month exposure.

The results obtained after various exposure times for the distinct accelerated tests are discussed to intend a sequence, time or order necessary to get most reliable results to those obtained during outdoor exposures. Also a relationship among the type of damage nucleated is intended when compared to the simulated natural environment. Similarities and differences, as much as time required initiating the different deffects are discussed.

Among the characteristics changing during accelerated tests of the 12 schemas of this type of

Table I. Characteristics of the tested materials

Tabla I. Características de los materiales ensayados

\begin{tabular}{|c|c|c|c|c|c|c|c|c|c|c|}
\hline \multirow{3}{*}{ Code } & \multirow{3}{*}{$\begin{array}{l}\text { Metallic } \\
\text { coating }\end{array}$} & \multirow{3}{*}{$\begin{array}{l}\text { Thickn. } \\
(\mu \mathrm{m})\end{array}$} & \multicolumn{8}{|c|}{ Paint } \\
\hline & & & \multicolumn{3}{|r|}{ Base } & \multicolumn{4}{|c|}{ Finishing } & \multirow{2}{*}{$\frac{\text { Total thick. }}{E(\mu \mathrm{m})}$} \\
\hline & & & Vehicle & Pigm. $\left.{ }^{* *}\right)$ & $E(\mu \mathrm{m})$ & Vehicle & Pigment & Colour & $E(\mu \mathrm{m})$ & \\
\hline A1 & Galvalume & 20 & Epoxy & $\mathrm{Ti}, \mathrm{Cr}, \mathrm{Co}, \mathrm{Al}$ & 4 & PVDF & $\mathrm{Al}, \mathrm{Ti}, \mathrm{Fe}, \mathrm{Si}$ & Light Blue & 20 & 44 \\
\hline A2 & $\mathrm{Zn}$ & 20 & Epoxy & $\mathrm{Fe}, \mathrm{Cr}, \mathrm{Zn}, \mathrm{Ti}$ & 6 & PVDF & $\mathrm{Fe}, \mathrm{Zn}, \mathrm{Si}$ & Blue & 17 & 43 \\
\hline A3 & $\mathrm{Zn}$ & 20 & Epoxy Acrilic & $\mathrm{Si}, \mathrm{Fe}, \mathrm{Ti}$ & 6 & Poly. Silic. & $\mathrm{Fe}, \mathrm{Si}, \mathrm{Pb}$ & Red & 17 & 43 \\
\hline A4 & Galvalume & 20 & Polyester & $\mathrm{Fe}, \mathrm{Si}, \mathrm{Ti}$ & 5 & Poly. Silic. & $\mathrm{Fe}, \mathrm{Si}, \mathrm{Al}, \mathrm{Ti}$ & Light Blue & 17 & 42 \\
\hline A5 & Galvalume & 20 & Epoxy & $\mathrm{Fe}, \mathrm{Si}, \mathrm{Ti}$ & 4 & PVDF & $\mathrm{Al}, \mathrm{Si}, \mathrm{Ti}$ & Red & 19 & 43 \\
\hline A6 & Galvalume & 20 & Polyester & Ti, Si, Al & 5 & Polyester & $\mathrm{Ti}, \mathrm{Si}, \mathrm{Al}$ & White & 18 & 43 \\
\hline $\mathrm{CH} 1$ & - & - & Epoxy & $\mathrm{Fe}, \mathrm{Si}$ & 15 & Polyester & $\mathrm{Fi}, \mathrm{Fe}, \mathrm{Al}, \mathrm{Si}$ & Beige & 15 & 30 \\
\hline $\mathrm{CH} 2$ & - & - & Epoxy & $\mathrm{Fe}, \mathrm{Si}$ & 15 & Polyester & $\mathrm{Fe}, \mathrm{Si}$ & Brown & 15 & 30 \\
\hline E1 & $\mathrm{Zn}$ & 20 & Polyester & $\mathrm{Ti}, \mathrm{Al}, \mathrm{Si}$ & 20 & Polyester & $\mathrm{Ti}, \mathrm{Al}, \mathrm{Si}$ & White & 15 & 55 \\
\hline E2 & $\mathrm{Zn}$ & 25 & Polyester & $\mathrm{Ti}, \mathrm{Cr}, \mathrm{Si}, \mathrm{Al}$ & 20 & Poly. Silic. & $\mathrm{Fe}, \mathrm{Si}, \mathrm{Ti}, \mathrm{Ca}$ & Red & 10 & 55 \\
\hline E3 & $\mathrm{Zn}$ & 20 & Epoxy Aminopl. & $\mathrm{Fe}, \mathrm{Ti}, \mathrm{Si}$ & 20 & PVDF & $\mathrm{Fe}, \mathrm{Al}, \mathrm{Si}$ & Green & 16 & 56 \\
\hline$(*) \mathrm{E} 4$ & $\mathrm{Zn}$ & 25 & - & - & - & Alcid. Melam. & $\mathrm{Ti}, \mathrm{Si}, \mathrm{Al}$ & White & 25 & 50 \\
\hline
\end{tabular}

(*) NILU (Norway)

$\left.{ }^{* *}\right)$ Elements detected through EDX, in decreasing order of relative abundance. 
materials, blistering and corrosion, both at the incision, are the most sensitive effects in all natural as also in simulated environments. Next, corrosion in the sample body away from the incision gives an idea of the porosity of the paint schema and reactivity of the respective metallic sustratum to the distinct accelerated ambients.

Representative single data, involving blistering size and density, were estimated on the basis of the proposal made by Keane et al. ${ }^{[12]}$ and shown in table II. Value 0 was assigned for the absence of failure and 5 for complete damage, according to the ISO scale of $4628 / 82-1$ standard $^{[6]}$.

Table II. Deterioration grade established as a function of blistering size and density

Tabla II. Deterioro establecido en función del tamaño y la densidad de ampollado

\begin{tabular}{llllll}
\hline SIZE & \multicolumn{5}{c}{ DENSITY } \\
\cline { 2 - 6 } & 1 & 2 & 3 & 4 & 5 \\
\hline S1 & 1 & 1 & 1 & 1 & 2 \\
S2 & 1 & 2 & 2 & 2 & 3 \\
S3 & 2 & 2 & 3 & 3 & 4 \\
S4 & 3 & 3 & 4 & 4 & 5 \\
S5 & 4 & 4 & 4 & 5 & 5 \\
\hline
\end{tabular}

\subsection{Prohesion test}

Prohesion is an accelerated test in which the samples are exposed to alternate cycles of saline fog $\left(\mathrm{NaCl} 0.05 \%\right.$ and $\left.\left(\mathrm{NH}_{4}\right)_{2} \mathrm{SO}_{4} 0.40 \%\right)$ and drying in a close laboratory chamber. For this test, onehour time were fixed for each cycle.

Samples of $10 \times 15 \mathrm{~cm}$ were tested, one of each material with a $2 \mathrm{~cm}$ incision from the bottom and $2 \mathrm{~cm}$ from each side, according to ISO 2409 ${ }^{[13]}$. Materials characteristics are shown in table III.

Periodically, the deterioration magnitude of the samples was evaluated, observing that the incision region was the most sensitive to corrosion and blistering, as can be seen in table IV. Samples showing the best and worst performances against the Prohesion test aggressive atmosphere were identified.

The evaluation of the corrosion grade was made according to ISO $4628 / 3$ standard $^{[8]}$. For visualising the percentage of corrosion in the incision, bars diagrams showing the corrosion grade of the samples for different test times were elaborated. At the incision, a visual estimation of the area percentage covered by corrosion products was carried out for different test times.

The performance observed for the 12 materials was discused according to the schema total

Table III. Tested samples. Those labelled with " $s$ " have no incision

Tabla III. Muestras ensayadas. Las designadas con " $s$ " no tienen incisión

\begin{tabular}{llcl}
\hline MATERIAL ORIGIN & CODE & MEDIUM THICKNESS $(\mu \mathrm{m})$ & \multicolumn{1}{c}{ CHARACTERISTICS } \\
\hline \multirow{4}{*}{ Argentina } & $\mathrm{A} 1$ & 46 & Galvalume + epoxy/PVDF \\
& $\mathrm{A} 2$ & 48 & Zn + epoxy/PVDF \\
& $\mathrm{A} 3$ & 47 & $\mathrm{Zn}+$ epoxy acrylic/PVDF \\
& $\mathrm{A} 4$ & 46 & Galvalume + polyester / siliconized polyester \\
& $\mathrm{A} 5$ & 51 & Galvalume + epoxy/siliconized polyester \\
Chile & $\mathrm{A} 6$ & 59 & Galvalume + polyester/polyester \\
& $\mathrm{CH} 1$ & 32 & Steel (epoxy/polyester) \\
& $\mathrm{CH} 2$ & 24 & Steel (epoxy/polyester) \\
& E1 & 37 & Zn (polyester/polyester) \\
Spain & E1s & 38 & Zn (polyester/polyester) \\
& E2 & 53 & Zn (polyester/siliconized polyester) \\
& E2s & 57 & Zn (polyester/siliconized polyester) \\
& E3 & 37 & Zn (epoxy aminoplaste/PVDF) \\
& E3s & 35 & Zn (epoxy aminoplaste/PVDF) \\
& E4 & 48 & Zn (Alcidic melamine) \\
& E4s & 53 & Zn (Alcidic melamine) \\
\hline
\end{tabular}


Table IV. Salt Spray Chamber - Time for failures initiation, in hours

Tabla IV. Cámara de Niebla Salina - Tiempo de inicio de falla, en horas

\begin{tabular}{|c|c|c|c|c|c|}
\hline \multirow[t]{2}{*}{ SAMPLE CODE } & \multicolumn{2}{|c|}{ BLISTERING } & \multicolumn{2}{|c|}{ CORROSION } & \multirow[t]{2}{*}{ OBSERVATIONS } \\
\hline & Body & Incision & Body & Incision & \\
\hline $\mathrm{A} 1$ & & 168 & & White & \\
\hline $\mathrm{A} 2$ & & & & White & Test finished at $3500 \mathrm{hs}$. \\
\hline $\mathrm{A} 3$ & & 1128 & & White & Best behaviour $\mathrm{A} 2$ \\
\hline A4 & & 3500 & & White & Worst behaviour $\mathrm{A} 1$ also in protected \\
\hline A5 & & 3500 & & White & borders in A4 and A5 \\
\hline A6 & & 3500 & & White & \\
\hline $\mathrm{CH} 1$ & 624 & & & 24 & Test finished at $1680 \mathrm{~h}$ \\
\hline $\mathrm{CH} 2$ & 624 & & & 24 & Similar behaviour in $\mathrm{CH} 1$ and $\mathrm{CH} 2$ \\
\hline E1 & 624 & 168 & & 24 & Test finished at 3500 hs. \\
\hline E2 & 624 & 168 & & 24 & Best behaviour E3. Worst behaviour E2 \\
\hline E3 & 3500 & 168 & & 24 & Blistering and white corrosion also in non- \\
\hline E4 & 1128 & 168 & & 24 & protected borders \\
\hline
\end{tabular}

thickness, metallic coating presence and composition, base and finishing paint coatings.

\subsubsection{Results of Prohesion test}

A1 to A6, samples

- Blistering on the body: A1 and A5 samples showed no blistering up to 1500 test hours, as can be seen in figure $1 \mathrm{a}$.

- Blistering at the incision: A4 sample showed the best behavior as can be seen in figure $1 \mathrm{c}$.

- Corrosion: Only sample A6 presented corrosion before 1500 test hours, showing the worst behavior.

- Corrosion \% at the incision: Best behavior was observed for samples A6, A4, A3 and A1, in decreasing order.

- Observations: At the end of the test similar aspects for all the samples, with little blisters in incisions and on the body of some of them was observed. At all the incisions white corrosion products were observed.

- Conclusion: Samples A1 and A4 showed the best behavior. In every sample the protector character of the Galvalume coating was appreciated.

$\mathrm{CH} 1$ and $\mathrm{CH} 2$ samples

- Blistering on the body: Similar for both (Fig. 1 a).
- Blistering at the incision: CH1 sample presented a better behavior than $\mathrm{CH} 2$ (Fig. $1 \mathrm{a}$ ).

- Corrosion: CH1 sample presented better behavior than $\mathrm{CH} 2$.

- Corrosion \% at the incision: Similar behavior for both.

- Observations: The most severely damaged on the whole body, with abundant corrosion products in incision and borders, was $\mathrm{CH} 2$.

- Conclusion: Best behavior is shown by $\mathrm{CH} 1$ sample.

E1 to E4 samples

- Blistering on the body: Best behavior in E2s, E3s and E4s samples. Better behavior was shown by samples without incision as shown figure $1 \mathrm{~b}$.

- Blistering at the incision: Samples E2 and E3 presented the best behavior as shown figure $1 \mathrm{~d}$.

- Corrosion: None presented corrosion.

- Corrosion \% at the incision: Sample E3 presented the best behavior.

- Observations: All samples presented incision deterioration, such as blistering, white corrosion products and disbonding. In samples E1 and E4 brown corrosion products were also observed. Samples E2s, E3s and E4s showed a better behavior than the respective with incisions.

- Conclusion: In general the best behavior was shown by sample E3. 


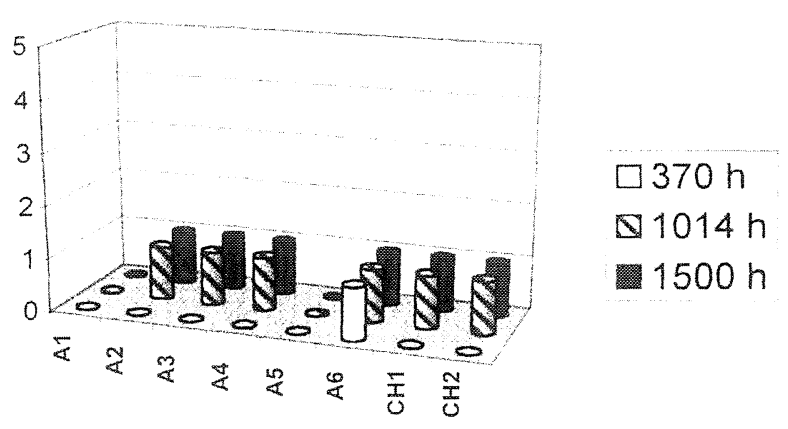

a)

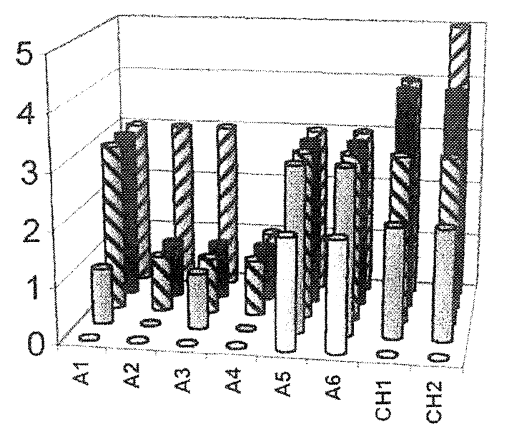

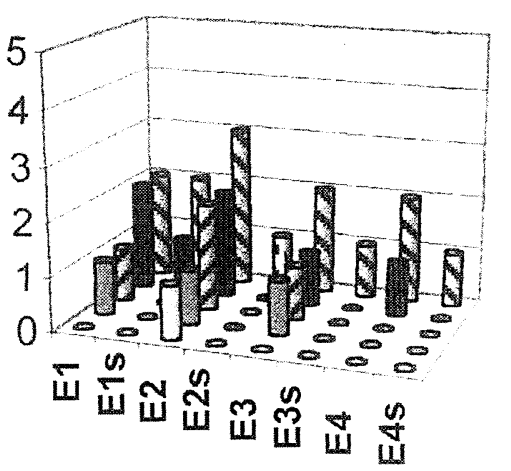

$\square 370 \mathrm{~h}$

$\square 572 \mathrm{~h}$

$\square 830 \mathrm{~h}$

$1014 h$

Q1500h

b)

c)

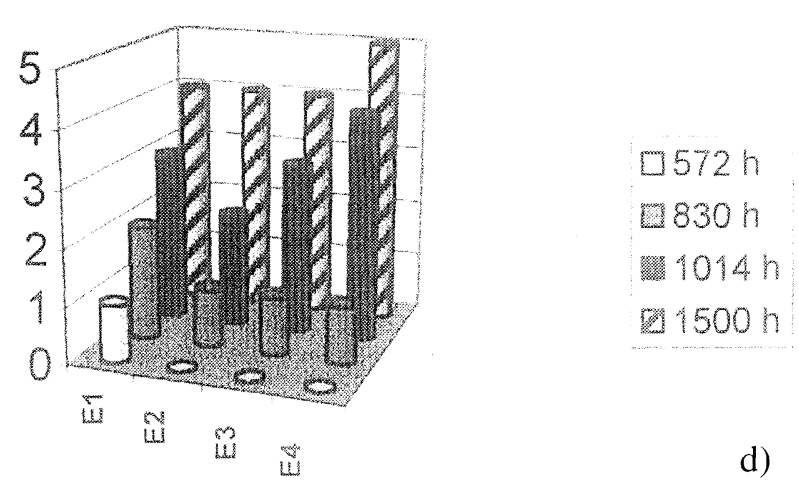

Figure 1. Blistering on the body for different exposure times of samples $A 1$ to $A 6, C H 1$ and $C H 2$ (a) and $E 1$ to $E 4$ (b); Blistering at incision for different exposure times of samples $\mathrm{Al}$ to $\mathrm{A6}, \mathrm{CH} 1$ and $\mathrm{CH} 2$ (c) and $\mathrm{El}$ to $\mathrm{E} 4$ (d).

Figura 1. Ampollado en el cuerpo para distintos tiempos de exposición de las muestras $\mathrm{Al}$ a A6, $\mathrm{CH} 1$ y $\mathrm{CH} 2$ (a) y El a E4 (b); Ampollado en la incisión para distintos tiempos de exposición de las muestras $\mathrm{Al}$ a A6, $\mathrm{CH} 1$ y $\mathrm{CH} 2$ (c) y El a E4 (d).

In the body zone of "samples"

- Deterioration such as small blistering (grade (1) was observed in most paint systems with the exception of A5, (epoxy acrylic/polyester siliconized finishing), which resisted 1500 hours test without failing and in the E2, E3 and E4 (melamine alcidic) that resisted more than $1000 \mathrm{~h}$ in the prohesion test without presenting this type of failure.

- Against corrosion the behaviour is best (grade (2). Only in some systems, such as in A6, which means in polyester/polyester paint systems and $\mathrm{CH} 1$ epoxy/polyester without metallic coating, $\mathrm{Zn}$ base, alquidic coatings and not over the grade 1 of the norm.

On the "incision"

- At $500 \mathrm{~h}$ all samples presented blistering near the incision, which increased with exposure time.
- Also, in very few hours all the samples evidence corrosion in the incision of the steel base schemas while in the galvanised ones more than $700 \mathrm{~h}$ were necessary for oxide points nucleation.

\subsubsection{Conclusions of Prohesion test}

- In the 12 coil-coating schemas tested, deterioration in the form of blistering and corrosion at incision occurred for all samples. Blistering increased in areas next or influenced by the incision.

- Cathodic protection by the $\mathrm{Zn}$ base coating occurred in areas with paint defects and incisions.

- Coil coatings present a good performance in spite of their low thickness $(35-50 \mu \mathrm{m})$ as steel protection schema. 


\subsection{Salt spray test}

International standards most generally applied to follow this test, evaluate samples and express results for different exposure times, are ASTM B $117^{[1]}$ and ISO $7253^{[2]}$. Results are shown in table IV.

\subsection{Moist $\mathrm{SO}_{2}$ test}

The ASTM G $87^{[4]}$ and ISO $3231^{[3]}$ are the international standards. Results are shown in table V.

\section{CONCLUSIONS}

From the results exposed for each accelerated test the following general conclusions can be obtained:

- Experimental results obtained show that each material appears as the best or the worst, depending on the type of failure evaluated (blistering, corrosion, gloss, color, etc.), even for the same accelerated test applied.also in natural environments, are corrosion and after blistering, both at incision.

- Metalic $\mathrm{Zn}$ based coatings increases time for red corrosion initiation in borders and incision.

- Thicknes of the overall protective schema decreases the sensitivity to blistering in the sample body.
- Metal Zn base coatings promote pore blockage in organic coatings, but when $\mathrm{Zn}$ corrosion is intense organic coating disbonding is produced. This also occurs in natural environments.

Differences in factors controlling coil coating failures in these laboratory tests as compared to outdoor tests, are:

- The strong effect of the sun radiation during outdoor test is not involved in the organic coating laboratory weathering processes.

- $100 \%$ TOW for salt spray tests form $\mathrm{Zn}$ corrosion products with lower protectiveness than during alternated dry and wet periods during outdoor exposures.

- $\mathrm{SO}_{2}$ chamber produces such acceleration in $\mathrm{Zn}$ corrosion that body blistering on all samples is highly promoted as compared to industrial or urban natural atmospheres.

\section{Acknowledgements}

The authors gratefully acknowledge to CYTED for financing the National Coordinators Meetings and to Bettina Marchisio for her assistance during the preparation of this paper.

Table V. Moist $\mathrm{SO}_{2}$ Test - Time for failures initiation, in $\mathrm{h}$

Tabla V. Ensayo de cámara húmeda de $\mathrm{SO}_{2}$ - Tiempo de inicio de fallo, en $h$

\begin{tabular}{|c|c|c|c|c|c|}
\hline \multirow[t]{2}{*}{ SAMPLE CODE } & \multicolumn{2}{|c|}{ BLISTERING } & \multicolumn{2}{|c|}{ CORROSION } & \multirow[t]{2}{*}{ OBSERVATIONS } \\
\hline & Body & Incision & Body & Incision & \\
\hline A1 & 96 & 480 & & 24 red & Best behavior $\mathrm{A} 2$ \\
\hline \multirow[t]{2}{*}{ A2 } & 1680 & 168 & & 24 grey & Worst behavior $A 6$ \\
\hline & & & & & $480 \mathrm{~h}$ corr. attenuated in $\mathrm{A} 3$ and at 1440 \\
\hline A3 & 168 & 168 & & 24 grey & 360 disbonding in A4 \\
\hline A4 & 96 & 360 & & 24 grey & 624 cracking in A5 \\
\hline A5 & 624 & 624 & & 24 white & Disbonding in incision in $A 6$ \\
\hline A6 & 480 & 360 & 1680 & 24 grey & Test finished at $1680 \mathrm{~h}$ \\
\hline $\mathrm{CH} 1$ & 168 & & & 24 & Similar behavior in $\mathrm{CH} 1$ and $\mathrm{CH} 2$ \\
\hline $\mathrm{CH} 2$ & 96 & & & 24 & Test finished at $360 \mathrm{~h}$ \\
\hline E1 & 440 & 168 & & 24 white & Best behavior in E3 \\
\hline \multirow[t]{2}{*}{ E2 } & 168 & 360 & 1680 & 24 white & Worst behavior E1 \\
\hline & & & & & 480 disbonding in borders in E2 \\
\hline E3 & & & & 24 white & 240 disbonding in E3 \\
\hline E4 & & & & 24 white & Test finished at $1680 \mathrm{~h}$ \\
\hline
\end{tabular}




\section{REFERENCES}

[1] ASTM B 117, Tentative method of salt spray (fog) testing.

[2] ISO 7253, Paints and vernishes- Determination of resitance to neutral salt spray.

[3] ISO 3231, Paints and vernishes. Determination of resistance to humide atmospheres containing sulphur dioxide.

[4] ASTM G 87, Practice for conducting moist $\mathrm{SO}_{2}$ test.

[5] ASTM 87, Modified salt spray test.

[6] ISO 4628/ 82-1, Paints and vernishes. General principles and rating schemes.

[7] ISO 4628/ 82-2, Paints and vernishes. Designation of degree of blistering.
[8] ISO 4628/ 82- 3, Paints and vernishes. Designation of degree of rusting.

[9] ISO 4628/ 82-4, Paints and vernishes. Designation of degree of cracking.

[10] ISO 4628/ 82- 5, Paints and vernishes. Designation of degree of flaking.

[11] ISO 4628/ 82-6, Paints and vernishes. Rating of degree of chalking by tape method.

[12] J.D. KEANE, J.A. BRUNO and E.F. WEAVER, Performance of alternative coating in the environment (PACE) Phase II Report, Dec. 79. SSPC, Pittsburgh, V-8.

[13] ISO 2409, Paints and vernishes. Cross cut test. 